dr hab. inż. Jerzy PYRCHLA ${ }^{1}$

bryg. dr inż. Jacek ZBOINA ${ }^{2}$

prof. dr hab. Mariusz ZIELIŃSKI ${ }^{3}$

Przyjęty/Accepted/Принята: 18.11.2013;

Zrecenzowany/Reviewed/Рецензирована: 23.05 .2014 ;

Opublikowany/Published/Опубликована: 30.09 .2014 ;

\title{
SYSTEM WIZYJNY DO NOCNYCH POSZUKIWAŃ NAWODNYCH ZINTEGROWANY Z LODZIĄ TYPU RIB (RIGID INFLATABLE BOAT) ${ }^{4}$
}

\author{
Night Vision System for Surface Water Search, Integrated \\ with Rigid Inflatable Boat
}

\section{Система ночного видения для поисковых работ на поверхности водоёмов, интегрированная с лодкой типа Rigid Inflatable Boat}

\begin{abstract}
Abstrakt
Cel: Przedstawienie przygotowanego rozwiązania na potrzeby ratownictwa wodnego składającego się z dedykowanej łodzi motorowej typu RIB dostosowanej do prowadzenia poszukiwań w nocy lub w warunkach ograniczonej widzialności oraz z systemu wizyjnokoordynacyjnego wspomagającego to działanie.

Wprowadzenie: System wizyjno-koordynacyjny oraz zintegrowanie go z dostosowaną łodzią motorową do prowadzenia poszukiwań $\mathrm{w}$ nocy realizowano $\mathrm{w}$ ramach projektu badawczego celowego nr UDA-POIG.01.04.00-22-008/11-00. Wszystkie prezentowane rozwiązania zostały przetestowane w warunkach rzeczywistych, przez specjalistów praktyków. Prezentowane rozwiązanie wpisuje się w priorytetowe kierunki badań naukowych i dotyczy obszaru technologicznego związanego z rozszerzeniem sfery bezpieczeństwa publicznego o okres nocny.

Wyniki: Technologią, która została opracowana, jest łódź motorowa dedykowana do poszukiwań nocnych, zintegrowana $\mathrm{z}$ systemem wizyjno-koordynacyjnym dla ratownictwa wodnego. W artykule przedstawiono efekty pracy nad projektem zmian konstrukcyjnych łodzi motorowej dostosowujących ją do zadań poszukiwawczo-ratowniczych realizowanych w nocy, jak również nad systemem wizyjnym dla wspomagania ratownictwa wodnego. Koncentrując się wokół problemów związanych z planowaniem poszukiwań nocnych na akwenach śródlądowych, przedstawiono algorytmy przebiegu i składowe procesu realizacji misji poszukiwawczoratowniczych. Szczególną uwagę zwrócono przy tym na wizualizację sytuacji w rejonie poszukiwań oraz wpływ na ich efektywność dostępu do danych środowiskowych. Zaprezentowano sieciocentryczną mapę wykonaną w technologii GIS, która pozwala wizualizować w postaci warstw aktualne i prognozowane warunki hydrologiczno-meteorologiczne. Przedstawiono propozycję skoordynowania ww. sieciocentrycznej mapy ze wsparciem informatyczno-organizacyjnym pozwalającym na poprawę dokładności lokalizacji łodzi z jednoczesną wizualizacją jej pozycji na mapie. Śródlądowe obszary wodne są niewielkie i dlatego pozyskiwanie danych hydrometeorologicznych z serwisów internetowych musi być interaktywne i pozwalać dostosowywać dane do sytuacji operacyjnej. Znaczenie kroku obliczeniowego przedstawiono na przykładzie obszaru Zatoki Gdańskiej przyległego do portu Gdynia wraz z basenami portowymi (zobrazowano go - z krokiem 1 mili morskiej oraz - z krokiem 0,1 mili morskiej).

Wnioski: Autorzy przedstawili sposoby planowania poszukiwań na akwenach wodnych w warunkach nocnych. Dotychczasowy system planowania wzbogacono o mapy elektroniczne zespolone z danymi środowiskowymi, pobieranymi automatycznie z serwisów internetowych. Zwiększono dokładność pozycjonowania podmiotów poszukujących, co przekłada się bezpośrednio na efektywność podejmowanych działań. Uzyskaną tym sposobem platformę sieciocentryczną można również wykorzystywać do symulowania działań poszukiwawczo-ratowniczych.
\end{abstract}

\footnotetext{
${ }^{1}$ Akademia Morska w Szczecinie, Wały Chrobrego 2, Szczecin / Maritime University of Szczecin, Poland;

${ }^{2}$ Centrum Naukowo-Badawcze Ochrony Przeciwpożarowej - Państwowy Instytut Badawczy, ul. Nadwiślańska 213, 05-420 Józefów; jzboina@cnbop.pl / Scientific and Research Centre for Protection - National Research Institute, Poland;

${ }^{3}$ Akademia Marynarki Wojennej im. Bohaterów Westerplatte; ul. Śmidowicza 69 Gdynia / Naval University of Gdynia, Poland;

${ }^{4}$ Wkład procentowy w powstanie artykułu / Percentage contribution: J. Pyrchla - 40\%, J. Zboina - 30\%, M. Zieliński - 30\%;
} 
Słowa kluczowe: ratownictwo wodne, System Informacji Geograficznej, GIS, sieciocentryczność, RIB, poszukiwania nawodne, elektroniczna mapa

Typ artykułu: oryginalny artykuł naukowy

\begin{abstract}
Goal: The main goal of the paper is to present a dedicated to water rescue speedboat (RIB type) adapted to conducting search at night or in low visibility conditions, as well as, a video-coordination system supporting rescue actions.

Introduction: The video-coordination system integrated with a speedboat for a night search was developed within the research project No. UDA-POIG.01.04.00-22-008/11-00. All presented results were tested in real conditions by specialist practitioners. What is more, presented solutions correspond with the priority directions of scientific and technological research areas associated with the improvement of public safety at night.

Results: A technology presented by the authors is a speedboat dedicated to night exploration (search), integrated with video-coordination system for water rescue. The paper describes the results of the project, aimed at introducing construction changes to a speedboat. These adapted the boat to search and rescue actions realised at night. The speedboat is also equipped with a video system supporting water rescue. To concentrate on the problems related to the planning of night actions on the inland waters, the algorithms of components of the implementation process of search and rescue actions were presented. Particular attention was paid to visualization of the situation in the area of exploration and the importance of the access to the environmental data. Presented network-centric charts were made in GIS technology which allowed to visualize in the form of layers current and forecasted hydrological and meteorological conditions. The paper showed a proposal of coordinating network-centric charts with the information and organizational support, thus allowing to improve the precision of the boat localisation and simultaneous visualisation of its position on the map. Inland water areas are small and, therefore, downloading hydrometeorological data from web services should be interactive. System has to adapt the data to the operational situation. An example of how important the calculation step is has been shown on the area of the Gulf of Gdansk, adjacent to the harbour of Gdynia with the docks depicted in steps of 1 nautical mile and in 0.1 nautical mile.

Conclusions: The authors presented planning methods of rescue research on water areas at night. The current planning system is enhanced with electronic maps combined with environmental data downloaded automatically from websites. While the accuracy of positioning seeking entities is enhanced, the effectiveness of taken actions is also better. The developed network-centric platform can also be used for simulation of search and rescue operations.
\end{abstract}

Keywords: water rescue, Geographic Information System, network centric warfare, RIB, surface search, electronic map. Type of article: original scientific article

\title{
Аннотация
}

Цель: Представление разработки для спасения на воде, которое состоит из специальной моторной лодки типа RIB (жестконадувной лодки), приспособленной для осуществления ночных поисков или в условиях ограниченной видимости, а также из координационной системы видения, поддерживающей такие действия.

Введение: Координационная система видения и ее интеграция с приспособленной моторной лодкой для проведения ночных поисков была разработана в рамках исследовательского целевого проекта номер UDA-POIG.01.04.00-22-008/11-00. Bce представленные решения были испытаны в реальных условиях и протестированы специалистами-практиками. Представленное решение является частью приоритетных научных направлений исследований области науки, касающейся технологической области, связанной с расширением сферы общественной безопасности ночного периода.

Результаты: Технологией, которая была разработана, является моторная лодка, предназначенная для ночных поисков, интегрированная с координационной системой видения для службы спасения на воде. В статье представлены результаты работы над проектом конструкционных изменений моторной лодки, направленных на ее приспособление к поисковоспасательным работам, реализованным ночью, а также над системой видения для служб спасения на воде. Обращая особое внимание на проблемы, связанные с планированием ночных поисков во внутренних водоёмах, представлены алгоритмы хода процесса осуществления поисково-спасательных миссий и его компоненты. Особое внимание было посвящено визуализации ситуации в районе поиска и влиянию доступа к информации об окружающей среде на его эффективность. Была представлена сетецентрическая карта, разработанная с использованием технологии GIS (географической информационной системы), которая позволяет изображать в виде слоев текущие и прогнозируемые гидро и - метеорологические условия. Было также представлено согласование сетецентрической карты с информационно-организационной поддержкой, которое позволяет повысить точность определения расположения лодки с одновременным отображением ее расположения на карте. Предложенное решение принимает во внимание тот факт, что внутренние водные водоёмы малы, и поэтому, скачивание гидрометеорологических данных с веб-сайтов должно происходить интерактивно. Расчеты, проведенные в этих центрах, должны приспосабливать расчётные действия к оперативной обстановке. Примером, показывающим на сколько важными являются расчётные действия, было представление территории Гданьского залива, прилегающего к порту Гдыня, вместе с бассейнами гавани, которые изображены с дискретностью 1 морской мили и с дискретностью 0,1 морской мили.

Выводы: Авторы представили способы и планирование поисков на водоемах в ночных условиях. Нынешняя система планирования была обогащена электронными картами в сочетании с данными о среде, которые автоматически загружаются с веб-сайтов. Повышена точность определения места нахождения искателей. Полученная этим образом сетецентрическая платформа может быть также использована для симуляции поисково-спасательных операций.

Ключевые слова: спасение на воде, Географическая Информационная Система (GIS), сетецентрический подход, RIB, поисковые работы на поверхности воды, электронная карта

Вид статьи: оригинальная научная статья 


\section{Wstęp}

Prezentacja różnych technicznych rozwiązań [1] na potrzeby ratownictwa wodnego, realizowanego przez Państwową Straż Pożarną i KSRG [2], to temat niezbyt często podejmowany $\mathrm{w}$ publikacjach $\mathrm{i}$ artykułach. Jednym z problemów, przed którymi stają ratownicy wodni $\mathrm{w}$ mundurach strażackich, jest prowadzenie działań w warunkach ograniczonej widoczności i w nocy. Ratownicze łodzie motorowe typu $\operatorname{RIB}^{5}$ [3] doskonale nadają się do prowadzenia poszukiwań nawodnych na śródlądowych i przybrzeżnych obszarach wodnych w warunkach dobrej widoczności. Nasuwa się jednak pytanie, co należałoby zrobić, aby wykorzystywać je w warunkach nocnych.

Państwowa Straż Pożarna stara się wciąż doskonalić swoje działania w zakresie ratowania życia ludzkiego. Ukierunkowane są one na dwa obszary, organizacyjny i sprzętowy. Pierwszy z wymienionych obszarów jest doskonalony poprzez ciągłe szkolenie i podnoszenie kwalifikacji operatorów-ratowników. Szkolenia idą w parze z pracami nad poszukiwaniem systemów wspomagających planowanie i koordynowanie akcji poszukiwawczo-ratowniczych. Drugi z obszarów jest rozwijany poprzez doposażenie ratowników w sprzęt techniczny (stacje radiolokacyjne, kamery telewizyjne i termowizyjne) do prowadzenia poszukiwania w każdych warunkach.

Odpowiadając na powyżej postawione pytanie, można stwierdzić, że skuteczne prowadzenie działań ratowniczych na wodzie w warunkach nocnych uwarunkowane jest odpowiednim przygotowaniem i wyposażeniem ratowników. Prowadzenie działań poszukiwawczo-ratowniczych w warunkach nocnych przy wykorzystaniu seryjnie produkowanych łodzi stwarza zagrożenie zarówno dla ratowników będących ich obsadami, jak i dla poszkodowanych, którym miałoby się udzielić pomocy. Przykładem rozwiązania wychodzącego naprzeciw problemom związanym z realizacją działań poszukiwawczo-ratowniczych $w$ nocy ${ }^{6}$ jest budowa łodzi motorowej, dostosowanej do prowadzenia poszukiwań w nocy i współdziałającej z systemem wizyjno-koordynacyjnym, realizowana w ramach projektu badawczego celowego przez firmę SPORTIS S.A. Ideę współdziałania łodzi ratowniczej z systemem wizyjno-koordynacyjnym przedstawiono na ryc. 1 .

Podstawowymi zadaniami zapewniającymi efektywność prowadzenia działań poszukiwawczo-ratowniczych

\footnotetext{
${ }_{5}^{5}$ ang. RIB (rigid inflatable boat) - łódź pneumatyczna ze sztywnym dnem.

${ }^{6}$ Przykład 1. 18 lipca 2010 - nie udało się odnaleźć czterech rybaków, którzy w sobotę zaginęli na Bałtyku. W nocy z soboty na niedzielę poszukiwania zawieszono.

Przykład 2. 6 grudnia 2008 - bez rezultatu zakończyły się poszukiwania mężczyzny, który wypadł z łódki na jeziorze Ilińskim koło Miłomłyna w woj. warmińsko-mazurskim. Ze względu na zapadający zmrok poszukiwania przerwano.

Przykład 3. 08 kwietnia 2013 świadkowie wyciągnęli z wody jedną z dwóch osób pracujących na łodzi. Do późnego popołudnia trwały poszukiwania drugiej osoby. Przeszukiwano też brzegi Wisły i zarośla. Ze względu na te warunki i zapadający zmrok poszukiwania przerwano.

Przykład 4. 21 sierpnia 2007 roku w ciągu kilku minut wiatr osiągnął prędkość 12 stopni w skali Beauforta, przewrócił i zatopił kilkadziesiąt jachtów. W nocy poszukiwania zawieszono.
}

w warunkach nocnych są dokładna lokalizacja łodzi oraz wizualizacja na mapie operacyjnej aktualnych i prognozowanych warunków hydrologiczno-meteorologicznych. Dostosowanie łodzi motorowej do działań w warunkach nocnych, jak również współdziałanie $\mathrm{z}$ systemem koordynacyjno-wizyjnym opracowanym na bazie GIS zostanie przedstawione $\mathrm{w}$ artykule. Prezentowane rozwiązanie wpisuje się w priorytetowe kierunki badań naukowych i dotyczy obszaru technologicznego związanego z rozszerzeniem sfery bezpieczeństwa publicznego o okres nocny.

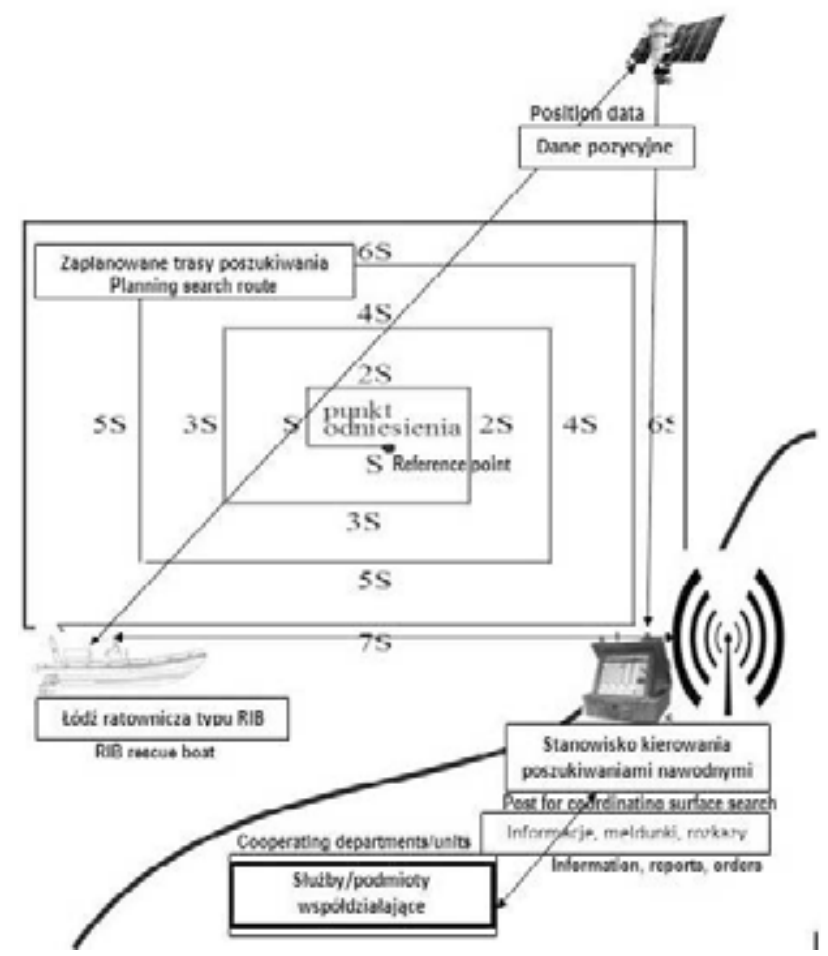

Ryc. 1. Organizacja działań w rejonie poszukiwania

Fig. 1. Organization of activities in the search area

\section{Etapy działań podejmowanych w trakcie poszukiwań nocnych}

Przebieg procesu poszukiwań nocnych na akwenach wodnych przedstawiony został na ryc. 2 przy pomocy diagramu typu SDL (ang. Specification and Description Language).

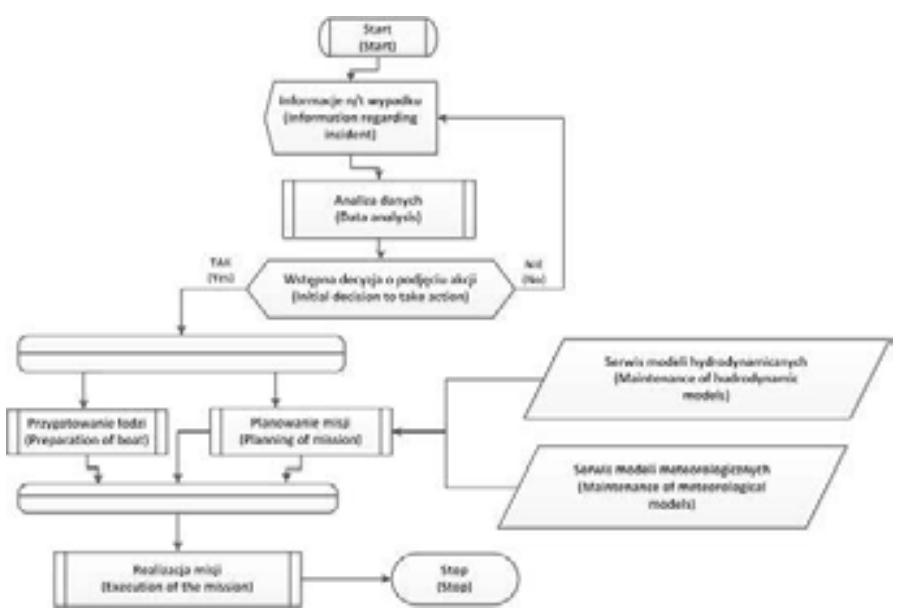

Ryc. 2. Przebieg i składowe procesu poszukiwań

Fig. 2. Course and components of the search process 
Poszczególne składowe przedstawione na diagramie należy rozumieć następująco. Początkiem procesu poszukiwań jest informacja pochodząca z zewnątrz wskazująca na potrzebę przeprowadzenia poszukiwań nocnych. Po dokonaniu analizy danych podejmowana jest wstępna decyzja o tym, czy podjąć poszukiwania. Jeśli decyzja jest pozytywna, inicjowane są jednocześnie dwa podprocesy:

- proces przygotowania łodzi, który dotyczy wszystkich aspektów logistycznych przedsięwzięcia;

- proces planowania misji, który dotyczy aspektów związanych z przetworzeniem posiadanych danych na temat zdarzenia będącego przyczyną inicjacji poszukiwania, a także pozyskaniem dalszych danych niezbędnych do planowania działań i wyznaczenia optymalnej trasy (schematu) poszukiwań.

Drugi z wyżej wymienionych procesów następuje przy wykorzystaniu serwisów zewnętrznych dostarczających dane na temat sytuacji meteorologicznej na obszarze poszukiwań oraz sytuacji hydrologicznej na akwenach potencjalnie wchodzących w skład tego obszaru.

Informacja o gotowości łodzi i jej obsady do rozpoczęcia misji, a także dane z podprocesu planowania wyzwalają rozpoczęcie kolejnego etapu działań tj. procesu realizacji misji. Proces ten przedstawiony został precyzyjniej na ryc. 3 .

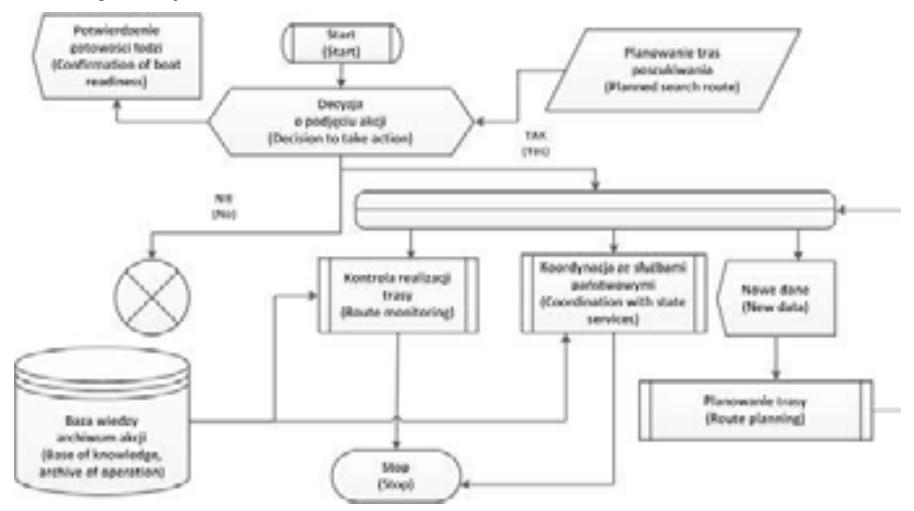

Ryc. 3. Przebieg i składowe procesu realizacji misji

Fig. 3. Course and components of the implementation of the mission

Jak już wspomniano, realizacja misji rozpoczyna się od podjęcia ostatecznej decyzji o jej podjęciu. Do tego potrzebne są: informacja o gotowości do działań zespołu poszukiwawczego (obejmująca również przemieszczenie do domniemanego/wskazanego rejonu zdarzenia) oraz plan działań przedstawiony tu jako planowana trasa poszukiwań. Podjęcie pozytywnej decyzji o celowości podjęcia akcji skutkuje inicjacją trzech procesów potomnych, to znaczy:

- procesu śledzenia i kontroli realizacji zaplanowanej trasy - obejmuje on również ciągłą komunikację z załogą łodzi;

- procesu koordynacji działań ze służbami państwowymi odpowiedzialnymi za ład i bezpieczeństwo;

- ciągłej analizy napływających danych, której skutkiem może być inicjowanie nowych/kolejnych dzia- łań i generowanie nowych tras poszukiwań przez odwołanie się do podprocesu planowania misji.

Należy zwrócić przy tym uwagę, że na ryc. 3 zaznaczony został również podsystem tak zwanej bazy wiedzy oraz archiwizacji zdarzeń. Odpowiedzialny jest on za lokalne przechowywanie informacji/danych na następujące tematy:

- ukształtowanie terenu (mapy akwenów i lądu);

- dane meteo- i hydrologiczne;

- dane o procedurach współdziałania ze służbami państwowymi odpowiedzialnymi za ład i bezpieczeństwo względnie innymi podmiotami współdziałającymi;

- dane na temat kontaktów, dyslokacji ww. służb/ podmiotów oraz podjętych działań i osiągniętych rezultatów (np. odnalezienie śladów zdarzenia kryzysowego, czy podjęcie z wody poszkodowanych).

Ponadto podsystem ten służy bieżącej archiwizacji zdarzeń w celu umożliwienia ich późniejszej analizy.

Główne wyzwanie związane z integracją GIS i ENC odnosi się do zbioru danych (w formacie S-57) i zamiana GIS danych przestrzennych formatu (s) do S-57 obiektu formatu albo vice versa tak, aby te dwie kategorie danych mogły być stosowane w przestrzennej analizie i podejmowaniu decyzji. Natomiast innowacyjne cechy opracowywanego systemu to:

- optymalizacja rozmieszczenia systemu noktowizyjnego, umieszczonego na łodzi typu RIB;

- możliwość kierowania działaniami łodzi ze stanowiska pomiarowego umieszczonego na brzegu akwenu (patrz ryc. 1);

- nawigacja pozwalająca na uzyskiwanie precyzyjnej dokładności (rzędu kilku cm);

- udoskonalony system pomiarowo-rejestrujący oraz usprawnienia w zakresie transmisji danych;

- szerokość pasa poszukiwania zoptymalizowana do warunków indywidualnego zbiornika wodnego.

Potrzebę korzystania z systemów integrujących informacje hydrometeorologiczne $\mathrm{z}$ informacjami geograficznymi wyraźnie widać, gdy przeanalizuje się zadania służb operacyjnych odpowiedzialnych za bezpieczeństwo na polskich akwenach wodnych. W tym kontekście przykładowe zadania to:

- planowanie użycia i wsparcia sił na akwenach wodnych,

- analiza i kontrola wyszkolenia sił planowanych do użycia,

- koordynacja działań sił przydzielonych do realizacji przedsięwzięć poszukiwawczo-ratowniczych,

- nadzór nad realizacją zadań z zakresu poszukiwawczo-ratowniczego,

- współpraca z instytucjami państwa w zakresie reagowania kryzysowego,

- zapewnienie ciągłości działania Krajowego Systemu Ratowniczo-Gaśniczego,

- zabezpieczenie hydrometeorologiczne sił,

- rozpoczęcie implementacji systemów wspomagania reagowania kryzysowego, 
- udział w ćwiczeniach narodowych i międzynarodowych.

Wymienione zadania uwidaczniają, że służby planujące i koordynujące działania ratownicze muszą korzystać $\mathrm{z}$ danych pochodzących $\mathrm{z}$ systemu danych nawigacyjnych, jak również danych pochodzących z systemu GIS. System nawigacyjny zapewnia głównie zobrazowanie mapy elektronicznej, pokazuje aktualną pozycję na niej i informację przyjętą od pokładowych sensorów. Najczęściej jest sprzęgnięty z Globalnym System Nawigacji Satelitarnej (np. GPS). Ma on funkcje aplikacji umożliwiającej aktualne zobrazowanie trasy żeglugi z jednoczesnym zapisywaniem danych obejmujących datę, czas, pozycję, kierunek przemieszczania się i prędkość łodzi.

\section{System wizyjno-koordynacyjny dla zabezpieczenia nawodnych działań poszukiwawczo-ratowniczych w warunkach nocnych}

Prowadzenie działań poszukiwawczo-ratowniczych na różnego rodzaju akwatoriach w warunkach ograniczających widzialność wiąże się z dysponowaniem zobrazowania aktualnej sytuacji w rejonie. Spełnienie tego wymogu gwarantuje technologia, która została opracowana i jest prezentowana, czyli system wizyjno-koordynacyjny (system sieciocentryczny), którego platformą integracyjną jest GIS. System taki jest w pełni skalowalny i znakomicie można go dostosowywać do rosnących wymagań. Uwagę poświęcono również dokładności lokalizacji łodzi ratowniczej i wpływowi na efektywność działań dostępu do danych środowiskowych.

Należy zauważyć, że strefa, którą obsada łodzi obserwuje (z wykorzystaniem noktowizorów) w nocy, jest duża (patrz ryc. 4), gdyż pozwala bezpiecznie sterować łodzią i prowadzić obserwacje, a jednocześnie mała, jeśli porównamy ją z zasięgiem obserwacji w okresie dziennym. Wyposażenie obsad łodzi w urządzenia optoelektroniczne pozwala prowadzić poszukiwania, ale jest zarazem na tyle ograniczone, że bez wsparcia informacyjnego nie może skutecznie wykonywać zadań. Wsparcie informacyjne musi być kompleksowe, czyli obejmować środowisko i jego stan tzn. geoinformację tj. dane o akwenie, panujące i prognozowane warunki hydrologiczne i meteorologiczne.

Śródlądowe obszary wodne, jak również morska strefa przybrzeżna charakteryzują się ogromną ilością geodanych, dlatego środowisko GIS było zawsze uznawane za najlepsze do gromadzenia i wizualizacji tych danych. Systemy oparte o to środowisko są integralnym komponentem w planowaniu i koordynowaniu działań na tych obszarach [3],[4]. Źródłem danych hydrologicznych i meteorologicznych są serwisy internetowe ośrodków rozpowszechniających te dane zróżnicowanymi urządzeniami do ich przekazu. Prowadząc badania nad zagadnieniem dopływu danych hydrologiczno-meteorologicznych do informacyjnego systemu wizyjno-koordynacyjnego, oceniono, że najlepsze rezultaty osiąga się, stosując sieciocentryczną mapę wykonaną w technologii GIS.

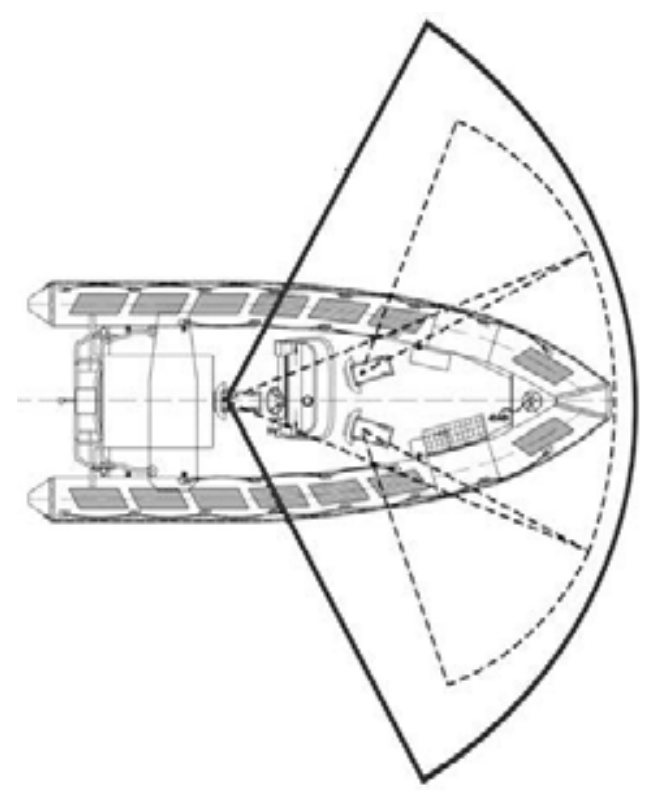

Ryc. 4. Kątowy zakres obserwacji obsady łodzi ratowniczej działającej w nocy (cienka linia) i w dzień (gruba linia)

Fig. 4. Angular range of observation of the rescue boat team at night

Podstawowym założeniem wykonania takiej mapy jest dostosowanie struktur zmodernizowanej geobazy tak, aby przechowywane dane opisujące atmosferę i hydrosferę miały możliwość dialogu (tzn. komponowania w dowolnym zestawieniu między sobą i z pozostałymi typami danych) oraz wykorzystania jako matrycy podstawowej do prognozowanego działania. Niezwykle ważna w odniesieniu do planowanych zastosowań jest możliwość zobrazowania aktualnej sytuacji w rejonie. Rozwiązanie takie można nazwać sieciocentrycznym, gdyż daje nadmiar informacji, co stanowi podstawową cechę tego typu systemów. Kolejną cechą jest skalowalność, co pozwala dostosowywać go do rosnących wymagań.

Sieciocentryczność jako pojęcie wiązało się pierwotnie przede wszystkim z zastosowaniami głównie wojskowymi, a pochodzi od anglojęzycznego określenia Network Centric Warfare (NCW), co można tłumaczyć jako „sieciocentryczne działania wojenne” [5]. Termin ten oznacza przetworzenie przez dowódcę (organ kierujący) przewagi informacyjnej na przewagę $\mathrm{w}$ dowodzeniu, a w konsekwencji na przeważające (również wyprzedzające) oddziaływanie. Przewaga ta osiągana jest na podstawie dostępnego dla dowódcy danego szczebla stale aktualizowanego (rozpoznanego), obszernego obrazu sytuacji. Aby obraz sytuacji był stabilny, pełny i aktualny, podmioty (struktury) pozyskujące, przetwarzające i wykorzystujące informację powinny być powiązane (najlepiej w czasie rzeczywistym) w zakresie wymiany informacji. Reasumując, głównym celem NCW jest uzyskanie supremacji w dziedzinie informacji dla zwiększenia efektywności prowadzenia działań [6]. Podobne do czysto wojskowych zastosowania i rezultaty można osiągać w systemach służących polepszeniu dyspozycyjności danych o sytuacji geograficznej pozyskiwanej dla celów planowania akcji poszukiwawczo-ratowniczych na akwenach wodnych. 
W systemie platformą integrującą wszystkie geoprzestrzenne dane cyfrowe pochodzące $\mathrm{z}$ różnych źródeł jest System Informacji Geograficznej [7]. Umożliwia to nakładanie na wspólną mapę-bazę różnorodnych warstw tematycznych takich jak: lądowe tereny przybrzeżne (np. mapy topograficzne, ortofotomapy), morskie elektroniczne mapy nawigacyjne (batymetria, oznakowanie nawigacyjne) oraz dane środowiskowe z numerycznych modeli pogody i hydrodynamicznych. System GIS pozwala łączyć dane cyfrowe zapisane w różnych standardach i odwzorowaniach (ryc. 5).

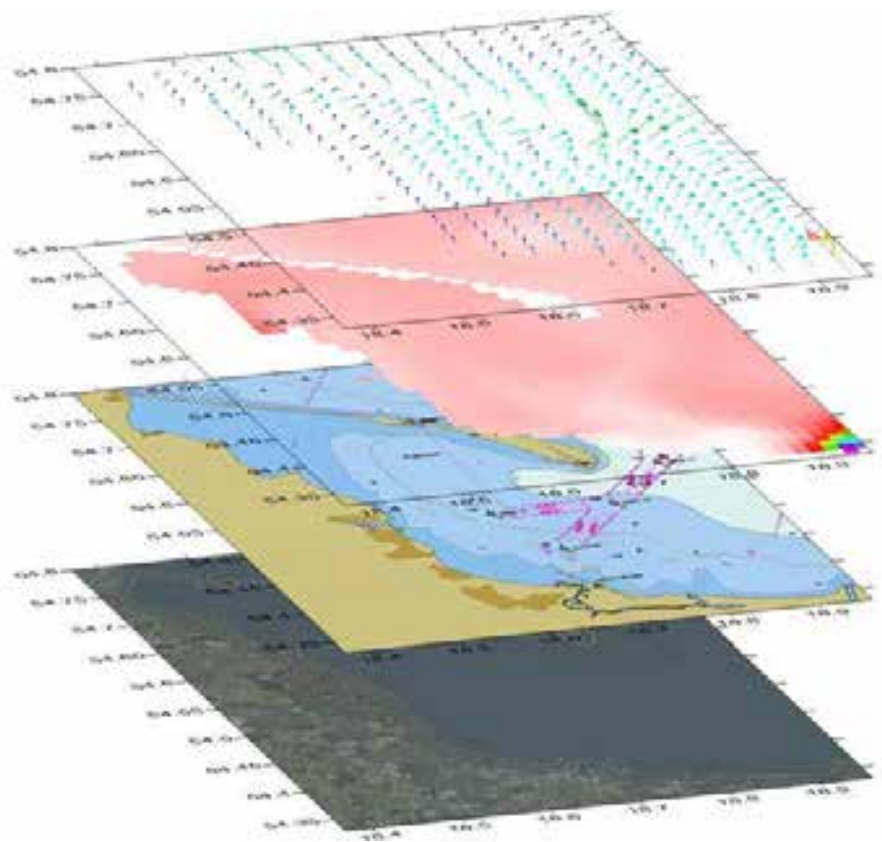

Ryc. 5. Mapy zapisane w różnych formatach i projekcjach geograficznych stanowiące warstwy tematyczne prezentowanego sytemu: a) ortofotomapa (format: GeoTIFF);

b) elektroniczna mapa nawigacyjna (standard S-57); c)

temperatura wody i prady z modelu hydrodynamicznego (format NetCDF)

Fig. 5. Maps in different formats and geographic projections, which are thematic layers of the present system: a) orthophotomap (format: GeoTIFF); b) electronic navigational map (standard S-57); c) water temperature and currents from the hydrodynamic model (format NetCDF)

W prezentowanym systemie ortofotomapa jest zapisana w formacie graficznym umożliwiającym dodawanie informacji georeferencyjnych (GeoTIFF) oraz w obowiązującym w Polsce dla map wielkoskalowych Państwowym Układzie Współrzędnych Geodezyjnych 2000 (PUWG 2000). Dane elektronicznej morskiej mapy nawigacyjnej dostarczone zostały w standardzie IHO ,Standard Wymiany Cyfrowych Danych Hydrograficznych S-57" (ang. IHO Transfer Standard for Digital Hydrographic Data - S-57) wykorzystywanym obecnie dla danych wektorowych. Wizualizację w zastosowanym systemie GIS (ArcGIS 10) oraz symbolizację oznaczeń nawigacyjnych zgodnie z powszechnie stosowaną na mapach morskich normą S-52 zapewnił dodatek: S-57 Viewer dla ArcGIS. Systemy GIS pozwalają także na import komórek morskiej mapy nawigacyjnej ENC (ang. Electronic Nautical Chart) w standardzie S-57 do geobazy, a dzięki temu umożliwiają wykonywanie analiz geoprzestrzennych.
W kontekście użytkowym system wizyjno-koordynacyjny został zaprojektowany w sposób, który pozwala na jego integrację z serwisami prognoz meteorologicznych i hydrodynamicznych, bazujących na modelach numerycznych: prądów wodnych, pogody i falowania. Dane z tych modeli pozwalają na zobrazowanie warunków środowiskowych na mapach, co w stosunku do tradycyjnych, tekstowych komunikatów meteorologicznych lub hydrologicznych jest dużym udogodnieniem. Możliwie prosta, a jednocześnie pewna wizualizacja danych jest szczególnie istotna $\mathrm{w}$ ograniczonych warunkach jednostki bezkabinowej. Zautomatyzowanie procesu akwizycji danych do systemu pozwala koordynatorowi akcji analizować jednocześnie informację o położeniu łodzi ratowniczej [8] wraz z informacją o warunkach meteorologicznych (np. prędkość wiatru, temperatura powietrza itp.) i hydrodynamicznych (np. wysokość fali, prędkość prądu, temperatura wody, poziom morza itp.). Integracja informacji środowiskowych jako jednej z warstw tematycznych na mapie systemu, przyczynia się do wspomagania decyzji podczas akcji poszukiwawczo-ratowniczych na akwenach wodnych [9].

Ważnym elementem współdziałania $\mathrm{z}$ serwisami internetowymi dostarczającymi informacje hydrometeorologiczne jest to, aby wersji operacyjnej modeli obliczenia mogły być przeprowadzane równolegle dla poszczególnych obszarów o różnych krokach przestrzennych. Przykładem mogą być dane z modelu M3D Wydziału Oceanografii Uniwersytetu Gdańskiego. Obszar Zatoki Gdańskiej przyległy do portu Gdynia wraz z basenami portowymi zobrazowano $-\mathrm{z}$ krokiem 1 mili morskiej ryc. 6a, oraz - z krokiem 0,1 mili morskiej ryc.6b [10]. Obliczenia w omawianym obszarze odbywają się równolegle, a wymiana informacji na wspólnej granicy odbywa się na każdym kroku czasowym [11]. Istnieje możliwość pozyskiwania informacji o prądach morskich na różnych głębokościach, gdyż w pionie stosuje się podział na warstwy o nieregularnej grubości [12]. W celu lepszego odwzorowania powierzchniowej i przydennej warstwy przyściennej stosuje się tam warstwy o mniejszej grubości niż pozostałe.

a)

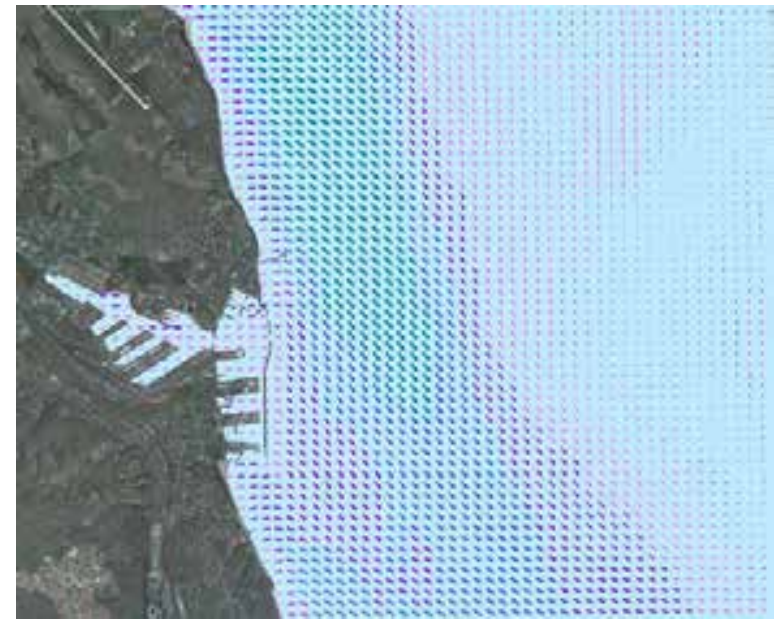




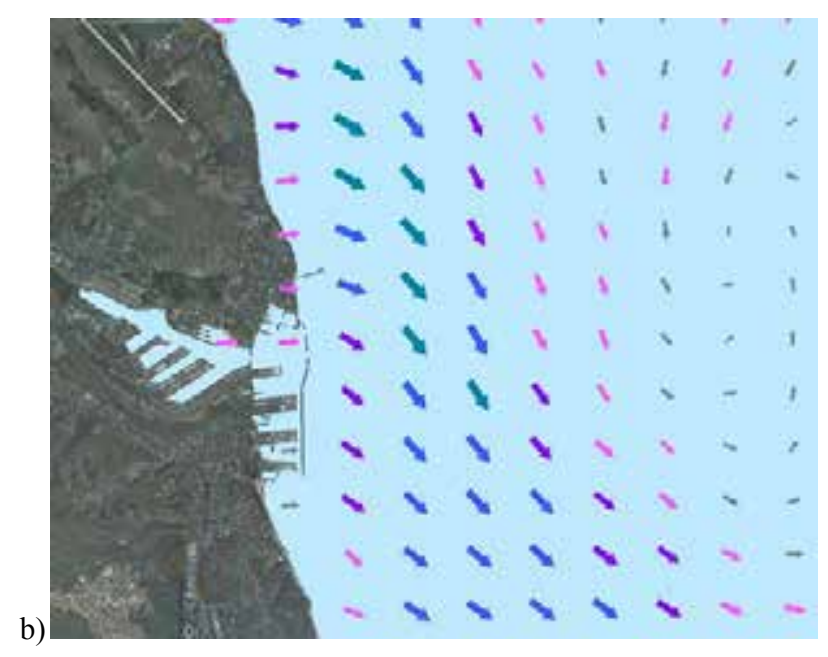

Ryc. 6. Integracja danych prądów morskich z Ortofotomapą: a) rozdzielczość $0,1 \mathrm{Nm}$; b) rozdzielczość $0,5 \mathrm{Nm}$.

Fig. 6. Integration of certain sea currents with Orthophotomap: a) resolution $0,1 \mathrm{Nm}$; b) resolution $0,5 \mathrm{Nm}$.

Wsparciem informatyczno-organizacyjnym planowania i koordynowania poszukiwań jest komputer wraz z opracowanymi dla tych celów programami informatycznymi. Takie rozwiązanie pozwala na uzyskanie większej dokładności pozycji łodzi ratowniczej niż przy standardowym pomiarze zainstalowanym na niej jednym odbiornikiem GPS. W tym kontekście w trakcie realizacji projektu opracowana została metoda uzyskiwania $20 \mathrm{~cm}$ dokładności pozycjonowania łodzi ratowniczej. Polega ona na wykorzystaniu do wyznaczania na bieżąco poprawek różnicowych dla poszczególnych satelitów poprzez odbiornik (stacjonarny) ustawiony w dokładnie wyznaczonym punkcie (np. przez pomiar geodezyjny). Drugi odbiornik (ruchomy) zainstalowany na łodzi przesyła pozycje za pomocą GSM do komputera znajdującego się na stanowisku kierowania. Poprawki są transmitowane również do tego samego komputera, co pozwala na wyeliminowanie większości błędów (gdyż błędy obserwowane na małym obszarze są skorelowane). Przyjęto, że czas rejestracji pozycji w poszczególnych danych jest jego stemplem, czyli identyfikatorem. Do wyznaczenia poprawionej pozycji łodzi wykorzystano skrypt napisany przez Kirka Kuykendalla. Takie rozwiązanie pozwala wizualizować pozycję łodzi na mapie obsługiwanej przez komputer punktu kierowania akcją z założoną dokładnością.

Przedstawione rozwiązanie pozwala uzyskać dokładność wystarczającą do koordynowania poszukiwań na akwenach wodnych w nocy, a jednocześnie obniżyć koszty całego systemu o zakup nawigacji inercyjnej. Doświadczenia wykonywane w trakcie realizacji projektu wykazały, że urządzenia nawigacji inercyjnej współpracujące z odbiornikami GPS używanymi na łodziach motorowych pozwalały uzyskiwać dokładność pozycji rzędu $15 \mathrm{~cm}$. Dokonując zestawienia kosztów urządzeń i dokładności pozycjonowania, uznano, że korzystniejsza i możliwa do stosowania na większą skalę jest przedstawiona powyżej metoda.

\section{Sprawdzenie lodzi motorowej dostosowanej do prowadzenia poszukiwań w nocy i systemu wizyjno- koordynacyjnego w warunkach rzeczywistych}

Głównym celem badań środowiskowych była praktyczna weryfikacja poprawności, skuteczności i efektywności działania zaproponowanego rozwiązania. W trakcie eksperymentów prowadzonych głównie na wodach Zatoki Gdańskiej, praktycznej weryfikacji poddane zostały zasadność zmian konstrukcyjnych na łodzi, jak również współdziałanie zlokalizowanego na brzegu systemu wizyjno-koordynacyjnego z łodzią. Każdy eksperyment był przeprowadzany w podobny sposób, w pierwszym etapie umieszczano cel poszukiwań - jedną z pław pomiarowych, na żądanej pozycji w wodach Zatoki Gdańskiej. Przyjęto, że z pewnymi uogólnieniami ten etap badań może odzwierciedlać zaistniały wypadek morski. Następnie przez pewien czas (od $1 \mathrm{~h}$ do $2 \mathrm{~h}$ ) pozwalano, by cel poszukiwań - pława pomiarowa, podobnie jak to się dzieje w rzeczywistych poszukiwaniach w sytuacjach SAR, swobodnie dryfowała pod naporem sił środowiska morskiego. W tym czasie dysponując już parametrami wejściowymi do obliczeń: pozycją zaistniałego wypadku morskiego - pozycją wystawienia pławy pomiarowej, parametrami geofizycznymi środowiska morskiego otaczającego cel poszukiwań oraz pewnymi przybliżeniami kształtu i charakterystyk dryfowych etc., dokonywano wstępnej symulacji scenariusza poszukiwań. Wszelkie obliczenia związane z planowanym wykonaniem praktycznego poszukiwania nawodnego wykonywane były przez system wizyjno-koordynacyjny. Po upływie zadanego czasu dryfowania rozwiązane zadanie poszukiwania nawodnego nanoszone było na mapę w postaci serii współrzędnych tzw. ,waypointów”.

$\mathrm{Na}$ pokładzie łodzi ratowniczej, podobnie jak to się dzieje w rzeczywistości, znajdowały się trzy osoby: sternik i dwóch obserwatorów, których zadaniem było odszukanie na powierzchni morza poszukiwanego obiektu - pławy pomiarowej w kolorze żółtym. Obserwatorzy poszukujący pławy pomiarowej byli wykwalifikowanymi motorowodniakami. Każdorazowo poszukiwania trwały do chwili wykrycia przez obserwatorów poszukiwanego obiektu. Zakończeniem każdej z prób było manewrowanie w pobliżu pławy na różnych kursach i w zróżnicowanym oświetleniu.

$\mathrm{W}$ trakcie doświadczenia na wodzie operator znajdujący się w brzegowym stanowisku kontrolnym miał podgląd na realizację zadania oraz ewentualne odchylenia od profili poszukiwania etc. Było to możliwe dzięki otrzymywaniu drogą radiową z odbiornika GPS, znajdującego się na pokładzie łodzi ratowniczej, ciągłej transmisji pozycji w standardzie NMEA 0183, która wczytywana była do elektronicznej mapy nawigacyjnej. Ponadto operator obsługujący brzegowe stanowisko kontrolne w każdej chwili mógł zlokalizować poszukiwany obiekt, dzięki zainstalowanemu wewnątrz pławy pomiarowej nadajnikowi GSM połączonemu z odbiornikiem systemu GPS. 
Eksperymenty prowadzone były w różnych warunkach hydrometeorologicznych, jak również w warunkach zróżnicowanego oświetlenia (księżyc). W trakcie doświadczenia przeprowadzany był eksperyment praktyczny związany $\mathrm{z}$ określeniem średniego zasięgu wykrycia dla wybranego celu, warunków hydrometeorologicznych i oświetlenia (księżyc).

Analizując zebrane, dane można było stwierdzić, że proponowane rozwiązanie jest poprawne pod względem przyjętych założeń. Wszystkie misje poszukiwawcze zakończyły się powodzeniem. Obiekt był wykrywany w różnych odległościach w zależności od oświetlenia pochodzącego od księżyca. Najlepsze rezultaty uzyskiwano, gdy księżyc był w pełni, ale przykryty cienka warstwą chmur. Należy wnioskować, że w takich warunkach następuje równomierne rozproszenie światła. Noktowizory w tych warunkach pozwalały wykrywać obiekt z $250 \mathrm{~m}$, a identyfikować z $170 \mathrm{~m}$. Podczas innych faz księżyca zasięgi wykrycia i identyfikacji zmniejszały się od 10 do 20 procent. Ważnym spostrzeżeniem jest również to, że prędkość poszukiwań musi być również dobierana w zależności od ilości światła.

\section{Podsumowanie}

Organizowany ze względu na swoją specyfikę system ratownictwa wodnego wydaje się być najbardziej podatny na implementację struktur sieciocentrycznych. W aspekcie sieci powiązań system wymiany informacji geograficznej wydaje się być, zdaniem autorów, elementem najbardziej dojrzałym do prób implementacji sieciocentryczności na gruncie polskim. $Z$ samej swej istoty system ten stanowił powiązania systemów na długo przed pojawieniem się pojęcia NCW.

W niniejszej pracy starano się wykazać, że właściwym sposobem radzenia sobie $\mathrm{z}$ integracją przestrzennych danych środowiskowych $\mathrm{w}$ procesie planowania działań operacyjnych w rejonie wód śródlądowych i przybrzeżnych jest usieciowienie sposobów powiązania informacji. Autorzy przedstawili sposoby, które można z powodzeniem wykorzystać do stworzenia podstaw planowania poszukiwań na akwenach wodnych w warunkach nocnych poprzez uzupełnianie dotychczasowego systemu o mapy elektroniczne zespolone $\mathrm{z}$ danymi środowiskowymi oraz równoczesne zwiększenie dokładności pozycjonowania podmiotów poszukujących. Uzyskana tym sposobem platforma sieciocentryczna pozwala również na wykorzystanie jej do symulowania działań.

Tym sposobem wyszczególnione na ryc. 1 brzegowe stanowisko kierowania poszukiwaniami nawodnymi sprowadzało się będzie li tylko do dysponowania na miejscu laptopem z systemem łączności.

Przedstawione rezultaty badawcze projektu wpisują się w Krajowy Program Badań. Założenia polityki naukowo-technicznej $i$ innowacyjnej państwa z 2011 r., gdzie w rozdziale VII (Bezpieczeństwo i obronność państwa) wskazuje się, że priorytetowymi obszarami rozwoju technologii w sferze bezpieczeństwa wewnętrznego są nowoczesne technologie i innowacyjne rozwiązania w zakresie wykrywania, zwalczania i neutralizacji zagrożeń, a $\mathrm{w}$ rozdz. IV - Technologie priorytetowe wynikajace ze zdolności operacyjnych w zakresie zarządzania informacją. Realizowany projekt odpowiada również na potrzeby rynku sprecyzowane w kolejnym dokumencie programowym pt. Dlugoterminowy plan rozwoju priorytetowych obszarów badawczych $w$ zakresie techniki i technologii obronnych na lata 2007-2019 z 2006 r. W rozdz. V Technologie przełomowe wskazuje się na potrzebę rozwijania - systemów informacyjnych. Obydwa wspomniane dokumenty są kompatybilne ze Strategia Rozwoju Systemu Bezpieczeństwa Narodowego RP 2012-2022 z 2012 r., jak również z Biała księga bezpieczeństwa narodowego $R P$ z 2013 r., gdzie odpowiednio rozdział IV wskazuje na potrzebę tworzenia warunków do rozwoju zintegrowanego systemu bezpieczeństwa narodowego (pkt 2 Cel 5), a rozdz. IV drugiego dokumentu pt. Koncepcja przygotowania systemu bezpieczeństwa narodowego traktuje o jego strategii preparacyjnej. Jak wynika z powyższych dokumentów, w obecnej sytuacji istnieje pilna potrzeba opracowania tematyki objętej niniejszym projektem.

Prezentowane rozwiązania mają zastosowanie w praktyce, stwarzając możliwości do skutecznego prowadzenia działań ratowniczych w warunkach ograniczonej widoczności i w nocy. Są to rozwiązania potrzebne i oczekiwane do wdrożenia, być może wymagające określonej implementacji i dostosowania do potrzeb i oczekiwań poszczególnych służb.

Prace badawcze finansowane były w ramach projektu celowego nr UDA-POIG.01.04.00-22-008/11-00, „Opracowanie innowacyjnego systemu wizyjnego dla ratownictwa wodnego przez firmę SPORTIS S.A." finansowanego ze środków Europejskiego Funduszu Rozwoju Regionalnego.

\section{Literatura}

1. Popis J., Możliwość wykorzystania węży pożarniczych W-75 w akcji ratowania tonacego, BiTP Vol. 17 Issue 1, 2010, pp. 141-146.

2. Zasady organizacji ratownictwa wodnego w Krajowym Systemie Ratowniczo-Gaśniczym, KG PSP, Warszawa, 2012.

3. Pyrchla J., Przyborski M., Środowiskowy system informacji geograficznej elementem zabezpieczenia działań operacyjnych w strefie przybrzeżnej, „Roczniki Geomatyki” Tom IX, Zeszyt 1, Warszawa, 2011.

4. Pyrchla J., Przyborski M., Fuzja systemów ECDIS i GIS na terenach portów, „Roczniki Geomatyki”, Tom IX, Zeszyt 1, Warszawa, 2011.

5. Zieliński M., Rozwiazania sieciocentryczne w siłach morskich, „Zeszyty Naukowe AON” Vol. 58 Issue 1, 2005.

6. Zieliński M., Cooperative Engagement Capabilitry (CEC), a obrona zespolu okrętów, Materiały z XI Konferencji nt.: „Automatyzacja dowodzenia”, Pieczyska, 2003.

7. Pyrchla J., Wplyw danych geoinformatycznych na planowanie akcji ratowniczych w polskiej strefie SAR, „Roczniki Geomatyki”, Tom VIII, Zeszyt 1, Warszawa, 2010.

8. Pyrchla J., Geoinformacja a ratownictwo morskie w świetle badań dryfu matych obiektów w rejonie Battyku Poludniowego, „Archiwum Fotogrametrii, Kartografii i Teledetekcji” Zeszyt XVIII, 2008.

9. Pyrchla J., Zastosowanie teorii zbiorów rozmytych do reprezentacji informacji wzrokowych wspomagajacych lokalizację obiektów na powierzchni morza, AGH Uczelniane Wydawnictwo Naukowo-Dydaktyczne, Kraków, 2008. 
10. Pyrchla J., Kowalewski M., Dokładność przestrzennych danych z hydrodynamicznych modeli Battyku a bezpieczeństwo w polskim rejonie odpowiedzialności SAR, „Archiwum Fotogrametrii, Kartografii i Teledetekcji” Zeszyt XIX, 2009.

11. Kowalewska-Kalkowska H., Kowalewski M., Hydrological forecasting in the Oder Estuary using a three-dimensional hydrodynamic model, "Hydrobiologia" Vol. 554 Issue 1, 2006.

12. Kowalewski M., An operational hydrodynamic model of the Gulf of Gdańsk, in Research works based on the ICM's UMPL numerical prediction system results, Wydawnictwo Uniwersytetu Warszawskiego, 2001.

dr hab. inż. Jerzy Pyrchla - absolwent Wyższej Szkoły Marynarki Wojennej, doktor habilitowany nauk technicznych w dyscyplinie geodezja i kartografia Wydziału Geodezji Górniczej i Inżynierii Środowiska Akademii Górniczo-Hutniczej w Krakowie, komandor rezerwy Marynarki Wojennej RP. Profesor Akademii Morskiej w Szczecinie.

bryg. dr inż. Jacek Zboina - pełni służbę w Centrum Naukowo-Badawczym Ochrony Przeciwpożarowej Pań- stwowym Instytucie Badawczym na stanowisku p.o. Dyrektora CNBOP-PIB. Specjalizuje się w ochronie przeciwpożarowej, technicznych systemach zabezpieczeń przeciwpożarowych oraz ocenie zgodności. Absolwent studiów dziennych inżynierskich i uzupełniających studiów magisterskich w Szkole Głównej Służby Pożarniczej, ukończył również studia podyplomowe Menedżer Innowacji w Szkole Głównej Handlowej w Warszawie. Stopień naukowy doktora nauk społecznych w zakresie nauk o bezpieczeństwie uzyskał w Akademii Marynarki Wojennej w Gdyni na Wydziale Dowodzenia i Operacji Morskich. Oficer PSP. Rzeczoznawca Komendanta Głównego PSP ds. zabezpieczeń przeciwpożarowych.

prof. dr hab. Mariusz Zieliński - absolwent Wyższej Szkoły Marynarki Wojennej, Akademii Wojskowej NAL NRD w Dreźnie oraz Akademii Dowodzenia Bundeswehry w Hamburgu, oficer rezerwy Marynarki Wojennej RP. Wizytator Polskiej Komisji Akredytacyjnej oraz ławnik Odwoławczej Izby Morskiej w Gdyni. Profesor Akademii Marynarki Wojennej oraz Wyższej Szkoły Administracji i Biznesu w Gdyni. 